\title{
A Case Report: A Penile Zipper Injury in the Hypospadias with Intact Preputium
}

\section{Olgu Sunumu: Sünnet Derisinin Sağlam Olduğu Hipospadiasta Penisin Fermuar Yaralanması}

\author{
Sevgi Büyükbeşe Sarsu1, Kamil Şahin2 \\ ${ }^{1}$ Gaziantep Children Hospital, Clinic of Pediatric Surgery, Gaziantep, Turkey \\ 2 Haseki Training and Research Hospital, Clinic of Pediatrics, Istanbul, Turkey
}

\begin{abstract}
The penile zipper injury usually happens as a result of the entrapment of the prepuce between the teeth of the zipper. A 13 -year-old, uncircumcised boy was admitted with the injury of the dorsal surface of his penis caused by the zipper of his pants. The patient was not wearing any underwear and the accident had happened when he zipped up his pants quickly. On examination, it was observed that the metal, teeth of the zipper had trapped approximately $25 \mathrm{~mm}$ of skin, and the attempts to remove the zipper with lubricant failed, so surgery was decided. The zipper was opened towards the proximity of prepuce as much as possible. It was detected that the patient had a coronal hypospadias and wings of the glans were open. While the patient was under general anesthesia the zipper was removed with lubricant. Circumcision was terminated, and the patient was given an appointment for the repair of the hypospadias. "Detailed physical examination should be provided before effective circumcision. To our knowledge the safety of circumcision has not been described for boys with hypospadias and concomitant penile zipper injuries.

Key Words: Penis, wounds and injuries, hypospadias
\end{abstract}

\section{ÖZET}

Penisin fermuar yaralanması genellikle sünnet derisi fermuar dişleri arasında sıkışması sonucu oluşur. On üç yaşındaki sünnetsiz erkek hasta, olayın 6 . saatinde penisin dorsal yüzeyi pantolonunun fermuarına sıkışması şikayeti ile kabul edildi. Hasta iç çamaşıı giymeyip, hızlı bir şekilde pantolonunun fermuarını çekmesi ile kaza olmuștu. Muavenede, metal dișleri sünnet derisini yakalayıp, fermuar mekanizması yaklaşık olarak $25 \mathrm{~mm}$ kapalı gözlendi. Yağ ile fermuarı açma girişimleri başarısız oldu. Operasyona karar verildi. Sünnet derisi, fermuar tarafından yakalanan yere kadar açıld. Hastanın koronal hypospadiası ve glans kanatlarının açık olduğu belirlendi. Sünnet, bu gözleme dayalı sonlandıııdı. Fermuar, sünnet derisinden çıkarıldı. Hastaya hipospadias onarımı için randevu verildi. Etkili sünnet öncesinde detaylı fizik muayene yapılması sağlanmalıdır. Bilgilerimize göre hipospadiasa penisin fermuar yaralanmasının eşlik ettiği erkek çocuklarda güvenli sünnet daha önce tanımlanmamışıır.

Anahtar Kelimeler: Penis, yaralar ve yaralanmalar, hipospadias

\section{Introduction}

The penile zipper injuries usually occur because of the entrapment of the prepuce between the teeth of the zipper. These injuries are not commonly observed (1), however, they are actually the most common cause of penile damage, especially in uncircumcised children $(2,3)$. Various techniques have been reported for the treatment of this condition (4), but none has been described for the treatment of the boys who had hypospadias.

\section{Case Report}

A 13-year-old, uncircumcised boy was admitted to the emergency department of the Pediatric Hospital of Gaziantep (Turkey). Six hours prior to his admission the dorsal surface of his penis had been entrapped by the zipper of his pants. The patient had not been wearing underwear and the accident had happened when he quickly zipped up his pants. When admitted, the patient was extremely agitated and in pain. Physical examination revealed that approximately $25 \mathrm{~mm}$ of 
skin was entrapped by the metal teeth of the zipper (Figure 1). There was minimal edema and slight bleeding on the skin, and because the patient was not cooperative, numerous attempts in the emergency room to remove the zipper by using lubricant failed. His family said they did not want any additional intervention; but they wanted to have him circumcised as soon as possible. In the theatre and under general anesthesia the prepuce was retracted to the extent permitted by the zipper, and during this procedure, we found that the patient had coronal hypospadias and wings of the glans were open. The circumcision was terminated based on this observation, and the zipper was removed using lubricant, without damaging the prepuce. The patient was discharged 6 hours later. Two weeks later, after the preputial edemas and abrasion had healed, the patient was back for hypospadias repair. Informed consent and ethics committee approval were obtained.

\section{Discussion}

The penile zipper injuries usually occur because of the entrapment of the prepuce or glans between the zipper teeth (5). Genital injury by a trouser zipper is a common injury in children (6), usually between the ages of two and twelve, but our patient was an uncircumcised 13-year-old. Although we believe that this injury is seen more often in people who do not wear underwear, more than half of the patients who were injured in this way were wearing underwear at the time of the accident. The most common observed symptoms include:

1) Edema.

2) Pain in the region of the entrapped tissue.

3) In case of severe injury, there may be a tissue loss due to necrosis, but this is rare (7). About $80 \%$ of these injuries can be treated by reversing the movement of the zipper. A number of methods have been described to accomplish this treatment. One of the most commonly implemented methods is the rapid unzipping of the zipper after tightening the skin (8). Flowerdrew and his friends also described a method of using wire or bone cutters, or a mini hacksaw to separate the medial parts of the zipper (5). This method requires the availability of the necessary instruments and general anaesthesia $(9,10)$. Also, it is necessary to be extremely careful if the medial bar is deep in the tissue, as cutting it may be both difficult and dangerous. In our case, we were unsuccessful when we attempted to divide the metal bar, but this may have been facilitated by the use of a lubricant. This method should not be pursued too aggressively as it may worsen the problem and aggravate the local edema. The patients with these types of injuries become extremely frightened because of unsuccessful and painful interventions. Therefore, local or general anesthesia is usually needed. Our patient was uncooperative despite the use of local anesthesia, resulting in the failure of the numerous treatment attempts in the emergency room. He had hypospadias, which has previously never been reported to accompany this type of injury. Hypospadias is encountered in 2-8 live births per 1000, and it is thought to be caused by the fusion of the urethral folds between the $8^{\text {th }}$ and $14^{\text {th }}$ gestational weeks. In $5 \%$ of hypospadias cases, the prepuce develops normally, covers the penis, and hides the hypospadias deformity. Therefore, all patients to undergo circumcision should be checked prior to the procedure to ensure that the urethral meatus is located at the end of the glans. Circumcision is also a commonly implemented, but aggressive method to release the entrapped foreskin in boys with penile zipper injuries.

The disadvantages of this approach include:

1) Development of edema.

2) Lack of psychological preparation, and cultural taboos; we decided not to circumcise the child in the present case. The physicians should keep in mind that patients with penile zipper injuries may also have hypospadias. Detailed physical examination should be provided before effective circumcision. To our knowledge the safety of circumcision has not been described for boys with hypospadias and concomitant penile zipper injuries.

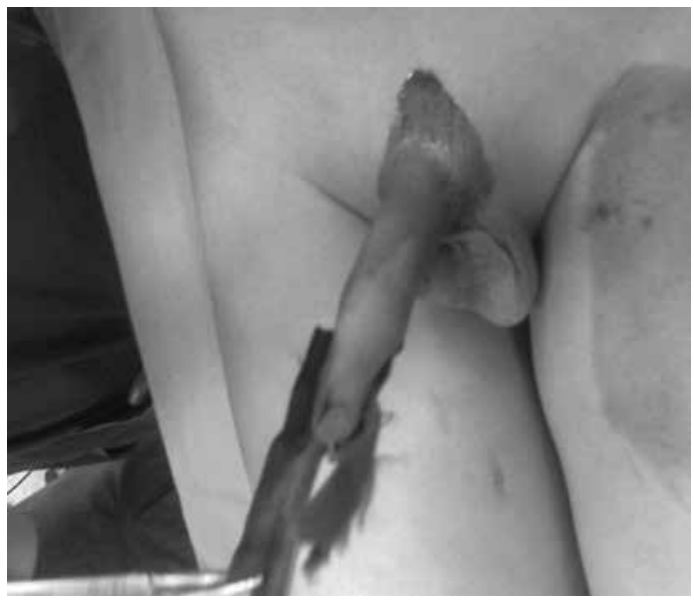

Figure 1. A physical examination revealed that approximately $25 \mathrm{~mm}$ of skin was entrapped in the metal teeth of the zipper

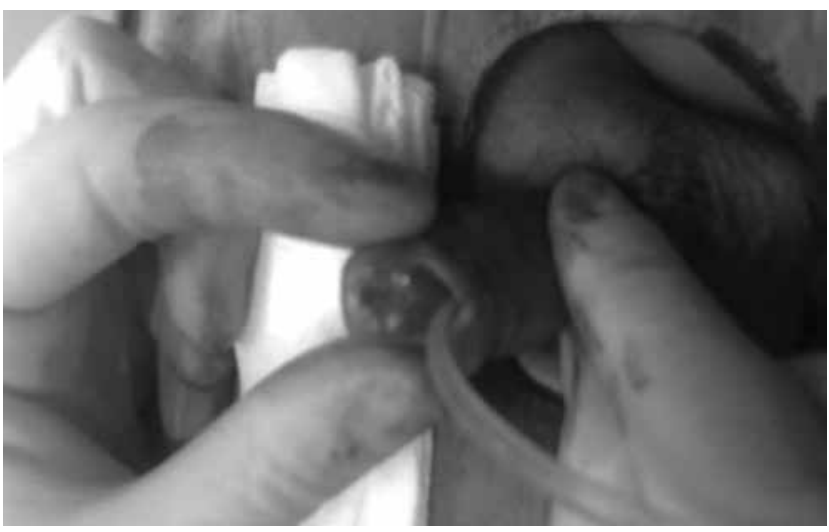

Figure 2. During this procedure, the patient was found to have coronal hypospadias and wings of the glans were open 
Informed Consent: Informed consent and ethics committee approval were obtained, Concept: Sevgi Büyükbeşe Sarsu, Design: Sevgi Büyükbeşe Sarsu, Data Collection or Processing: Sevgi Büyükbeşe Sarsu, Analysis or Interpretation: Sevgi Büyükbeşe Sarsu, Kamil Şahin, Literature Search: Kamil Şahin, Writing: Sevgi Büyükbeşe Sarsu, Peer-review: External and Internal peer-reviewed, Conflict of Interest: No conflict of interest was declared by the authors, Financial Disclosure: The authors declared that this study has received no financial support.

\section{References}

1. Mydlo JH, Harris FC, Brown JG. The Blunt, penetrating and ischemic injuries of the penis. J Urol 2002; 168:1433-5.

2. Yip A, Ng SK, Wong WC, Li, MK, Lam KH. The Injury of the prepuce. Br J Urol 1989; 63:535-8.
3. Fein JA, Zderic SA. The Management of the zipper injuries. In: King C, Henretig FM eds. The Textbook of the pediatric emergency procedures, 2nd edn. Philadelphia, Lippincott, Williams \& Wilkins, 2008:908.

4. Oosterlinck W. the Unbloody management of the penile zipper injury. Eur Urol 1981; 7:365-6.

5. Flowerdew R, Fishman IJ, Churchill BM. The Management of the penile zipper injury. J Urol 1977; 117:671.

6. Wyatt JP, Scobie WG. The management of penile zipper entrapment in children. Injury 1994; 25:59-60.

7. Inoue N, Crook SC, Yamamoto LG. The Comparing of 2 methods of the emergent zipper release. Am J Emerg Med 2005; 23:480-2.

8. Watson CC. Zipper injuries. Clinical Pediatric 1971; 10:188.

9. Nakagawa T, Toguri AG. The Penile zipper injury. Med Princ Pract 2006; 15:303-4.

10. Mishra SC. The Safe and painless manipulation of the penile zipper entrapment. Indian Pediatr 2006; 43:252-4. 